\author{
Sustinere \\ Journal of Environment and Sustainability \\ Volume 3 Issue 3 (2019) 144-169 \\ Print ISSN: 2549-1245 Online ISSN: 2549-1253 \\ Website: https://sustinerejes.com E-mail: sustinere.jes@iain-surakarta.ac.id
}

\title{
RESEARCH PAPER \\ The engaging of early age children in environmental behavior through wayang kancil folktale
}

\author{
Wakhid Musthofa ${ }^{1 *}$, Koentjoro Koentjoro ${ }^{2}$ \\ 1. Dept. of Islamic Psychology, Faculty of Ushuluddin and Da'wah IAIN Surakarta, Surakarta, Indonesia \\ 2. Faculty of Psychology, Universitas Gadjah Mada, Yogyakarta, Indonesia \\ Article history: \\ Received 6 May 2019 | Accepted 14 November 2019| Available online 4 December 2019
}

\begin{abstract}
School is a medium to solve the waste problem through clean lifestyle psychoeducation. Wayang kancil folktale uses animal characters as an alternative method to teach early age children to reduce littering behavior. This approach is applied because the animal world is close to the children's world. In addition, an interaction between children and the storyteller through folktale occurs during wayang kancil show. This study is action research which involves 14 second-year nursery student from a pre-school institution in Yogyakarta. The A-B-A experiment design puts the hypotheses of wayang kancil folktale to stimulate littering behavior at an early age to the test. Baseline, intervention, and reversal measurement was conducted consecutively for nine days which was recorded in observation sheets. Comprehension test was carried out before and after the intervention. The observation result was analyzed using visual analysis. Meanwhile, a comprehension score is rated by implemented paired sample $t$-test. The coefficient of reliability test of inter-rater was 0.971 . Pre and post-intervention comprehension score increased rapidly $(p=0.000$; < 0.01 ). The result proves that wayang kancil folktale was able to reduce children's littering behavior.
\end{abstract}

Keywords: folktale; environmental behavior; environmental education; littering behavior; wayang kancil

\section{Introduction}

Waste is everyone's concern (Wilson et al., 2015). The ignorance towards waste is the problem of the whole world. According to Goncharova (2012), environmental education for early age children is very important because it improves the quality of the planet. The damages caused by waste are the damaged ozone layer that triggers global warming, water pollution that threatens animal's genetics and reproduction, and metal emission that affects the health of all living things (Darmono, 2010). Therefore, littering behavior should be paid attention and the education to it must be given to children

${ }^{*}$ Corresponding author. E-mail: wakhidmusthofa@gmail.com

DOI 10.22515/sustinere.jes.v3i3.72 
A survey on environmental awareness in Yogyakarta proves that society's awareness of the environment is low (Kiswanto \& Pitoyo, 2016). The level of environmental knowledge of the students in International Islamic University Malaysia was 55\% reside at the medium level (Ibrahim \& Asmawi, 2012). Unsatisfactory result of the environmental awareness of the students of Govt. V.Y.T. Post Graduate Autonomous College showed 75.60\% arts students, 36\% commerce students and $34.37 \%$ of students from science reported had low awareness towards environment conservation and environmental problems (Sahu et al., 2015). Teaching and learning process toward sustainable development needs to be emphasized because the preservice teachers have a low level of awareness and understanding of concepts central to sustainable development compare to traditional environmental concepts (Karpudewan et al., 2013). Students did not have skills and awareness to identify and solve environmental problems such as population explosion, exhaustion of natural resources and pollution (Thote, 2013). The importance of controlling the excessive use of plastic additives and to introduce certain legislation and policies could be done by promoting plastic awareness programs through different social and information media (Sharma, 2017).

Meanwhile, Indonesia was the second country that mostly throw plastic waste to the sea after China, with the Philippines, Vietnam and Sri Lanka closing in behind (Jambeck et al., 2015). It was estimated that Indonesia consumed 700 plastic bags each year per person. A nondegradable plastic bags threats living things and the ecosystem. Marine animals are mostly affected through entanglement in and ingestion of plastic litter. According to Derraik's (2002) study, plastic particles were found in 8 of the 11 seabird species stomachs, affects a significant number of 267 species worldwide including 0.86 of all sea turtle species, 0.44 of all seabird species, and 0.43 of all marine mammal species. The accumulation of micro-plastics in the marine organism's cells and tissues developed as a chronic biological effect. The hazardous effects on human beings by alternate ingestion of micro-particles cause alteration in chromosomes which lead to infertility, obesity, and cancer (Sharma, 2017). Developing biodegradable plastics as a means of reducing the persistence of litter, but the effects on marine assemblages or ecosystem functioning have never been evaluated (Green e al., 2015).

The research about construction waste generation and management practice in Thailand shows that a major source of waste is yet to be effectively managed and recycled (Kofoworola \& Gheewala, 2009). Technology and knowledge management become one of three key areas to be prioritized in the action of healthcare waste management in Asia (Ananth et al., 2010). This result indicates the importance of knowledge about solid waste management.

A careless act of littering behavior and problems related to waste management attracts researchers to study the importance of environment-related education, especially on treatment towards waste. It would be better if environmental education starts at an early age. The attitudes and values of children need to be shaped at an early age as a means of environmental preservation and protection (Aini \& Laily, 2010; Basile, 2000; Bierhoff, 2001; Wilson, 1994). Early age is the best period to build positive skills because children are active learners (Bredekamp \& Copple, 1997). Pre-school children who studied and spent more in the nursery are the most educable and receive models, so that becomes a suitable time and place in enhancing environmental knowledge (Meiboudi et al., 2011). 
Littering behavior reduction programs could be taught and given to the children through activities that involve the teacher as a role model in the learning process. The teacher has aims to explore concepts, scenarios, and strategies of environmental preservation, encouraging children to become active participants in preserving the planet and promoting environmentally responsible behavior (Goncharova, 2012). Kos et al. (2016) emphasize the support and interactions from adults are necessary to bridge the gap between experience and knowledge construction, and new comprehension on early age. Despite the program being arranged by adults, the execution also involves the children's initiative.

The objectives of this research are to determine whether children can actively be engaged in the program of reducing littering behavior psychoeducation conducted by folktale conveyed using wayang kancil. The early age children's engagement in the environmental program will enhance environmental knowledge and their awareness. Besides, research will examine the role of folktale using wayang kancil as a medium in increasing environmental awareness, specifically on reducing littering behavior on early aged children.

\section{Literature review}

Tuncay et al. (2011) highlight most of the environmental problems, mainly caused by human activity. Therefore, to find solutions to environmental problems one precondition is making changes in human behavior. To resolve the question of the behavior of littering, it is necessary to change the behavior of carelessly throw garbage into not arbitrary or misplaced. The behavior of disposing of waste in its place is the form of environmental caring (Tarnoto, 2013; Wardani, 2015).

Kos et al. (2016) stated that in the preschool period, children have been able to understand the scientific background and the impact of environmental awareness behaviors when presented in accordance with the stages of his age. According to Grodzińska-Jurczak (Kos, 2016), children 3-4 years old are able to identify improper behavior on the environment using a set of pictures showing the positive and negative attitudes. Other studies about attitudes towards the environment conducted qualitatively by Kahriman-Ozturk et al. (2012). According to Ogelman (2012), environmental education in many countries has been prepared for early childhood, for example, in New South Wales, Little Green Step program for children ages 3-5 years. Most environmental education combines more than one topic such as water, animals, and garbage.

Many countries in the world have implemented the teaching of environmental awareness in schools, such as Greece, Australia, and Turkey. Greek teaches environmental concerns early on to teachers and teachers giving it to children (Flogaitis et al., 2005). The Australian Government implementing environmental awareness programs for children. The program is provided useful for the knowledge, skills, and behavior of children so that children are more responsible to the environment (Boyle, 2006). In Turkey, the environmental education of children of early age organized by the Ministry of National Education Early Childhood Education section. The program requires teachers to develop knowledge on the topic and the natural environment and also they have to plan a variety of activities associated with the additional knowledge in the daily activities of the students. It aims to build positive attitudes and behavior of children in the pattern of consumption, environmental protection, recycling and reuse and habits of life (Ertürk et al., 2015). 
There are fundamental reasons why environmental education should begin at an early age (Yoleri, 2012). First of all, the early years of children's lives is a golden opportunity to teach them about respect and build awareness towards the environment. If it is too late, then the awareness would not be fully constructed. Secondly, environmental education and positive interaction towards nature is an essential component of a healthy kids' character building. It will contribute to positive behavior and an individual's living quality from a young age onwards. Early childhood education (ECE) is an educational institution specifically established for children aged 0-6 years old (Suyadi, 2014).

Environmental awareness education is a part of character building (Kementerian Pendidikan dan Kebudayaan, 2012). Character education is the children's process of development to understand, commit, and act according to the existing norms (Wardani, 2015). Parents, teachers, and adults surrounding the students also play a role in helping children to be more aware, independent, and responsible. Musser and Diamond (1999) stated that the attitude and behavior of environmental caring could be observed as a part of the development of prosocial attitude. Yanuvianti (2008) argues that disposing of waste behavior in its place is one form of positive prosocial behavior. The prosocial behavior is a voluntary, intended behavior to help or benefit others, both individuals and groups.

Musser and Diamond's (1999) research on the development of prosocial attitudes greatly influenced by the theories of social learning theory (SLT). According to SLT, learning takes place primarily through observation of others called model, through experience and direct teaching as the opinion of (Bandura, 1986). The process of model behavior teaching in this research refers to modeling theory by Bandura (1986). Bandura (1986) explains that the modeling process consists of four processes, namely the processes of attention, retention, production, and motivation. At this stage of the process of attention, a child will observe a model that interests him, like a dress, diction, and the behavior of the model. Further information he obtained inserted into the memory in the form of codes of symbolic, this stage is referred to as the retention process. Through the symbolic media, then the experience is temporary can be stored in permanent memory. The next stage is the production process, i.e. changing the form of symbolic concepts into behavior according to the model. Furthermore, the last stage is the process of motivation, where a child is encouraged to bring behavior in accordance with the model he had learned before.

Teachers provide a behavior model as an example to children as a stimulation (Eisenberg \& Mussen, 2003). Real behavior of parents, teachers or peers can be a model, but fairytale can be a model to teach environmental behavior as well (Winarsih, 2014). Fairytale is very close to human life. Bishop and Kimball (2006) point out that the fairytale is an old art and always used in everyday life. Tale is one of the effective strategies used by teachers to instill character education to students. Students prefer tale method that is well told and truly inspiring, compared with admonitions or criticism (Sanchez \& Stewart, 2006). Fairytale is proven to increase prosocial skills and decrease aggressive behavior in nursery children (DeRosier \& Mercer, 2007) and increase knowledge about early childhood prosocial behavior (Winarsih, 2014). Suhantojo's (2013) study on 3rd-grade students suggests that after they are given fairy tale there was an increase in knowledge of the student to classify solid waste based on its type, whilst there was a reduction on the bad behavior of waste disposal. 
In the cognitive approach, the most important thing is to change the attitudes and behavior of littering by changing the perspective of the individual called the persuasion process which can be done through various media such as advertisements, brochures, education and environmental education (Tondok, 2006). Giving knowledge was helping in encouraging proenvironmental behavior, though not enough to encourage the desired behavior change. Therefore, this study aims to change behaviors with psychoeducation in early childhood to reduce littering behavior. To impart knowledge and moral messages as the fundamental factors for changing the behavior of littering this research used a wayang kancil folktale as a psychoeducation delivery media. Calvert (2007) points out that the story of fables is one method that can be used to cultivate the children's ability to philosophize and deliver a moral message to children. Since children at the age of 6 years have been able to understand the metaphor messages contained in the fables.

According to Santrock (2002), early age children's development takes place during their 2-7 years old. According to Piaget (Hetherington et al., 1999), a period of children around 2-7 years old is called the preoperational stage. During this stage, children learn to use and present objects through images and words. Also, during this time, there is an elaboration from symbolic functions that leads to vocabulary expansion, imaginative play, and imitation process. Jean Piaget (Monks et al., 2001) explains that when children are on their preoperational stage, they could imitate the acts that they see, or even what they had seen a day before. However, these children still need a tool or real experience to help them grasp abstract concepts. Therefore, a media for educating early age children to reduce littering behavior is necessary. Wayang kancil is an alternative media that can be used as a model for practicing behavior to reduce littering through its stories and activities. Winarsih (2014) has proven that Bandura's theory of modeling applied four stages, i.e. attention, retention, reproduction, and motivation, using wayang kancil folktales was affective to teach the prosocial helping behavior as a form of character education. Education about solid waste disposal behavior to children is a type of character building for children to develop environmental awareness that should be shaped at an early age.

Model and example could be delivered through folktales, in addition, the real model from the teachers, parents, or peers (Winarsih, 2014). Folktales' contents are relatively close to human's life. Bishop and Kimball (2006) propose that folktale is an old artwork, and everlastingly applied in daily life. Folktale could benefit in establishing children's speaking and listening skill as a stimulus of thinking ability in discussing about social awareness, creativity, vocabulary building, and children's emotion (Eades, 2005; Wright et al., 2008), emotionallymoving people by feeling happy or angry (Frude \& Killick, 2011) and expand self-capability in solving a problem (Edwards, 2009). Moreover, students are easier in learning and recalling knowledge conveyed through folktales, rather than knowledge conveyed in an informative manner (Bishop \& Kimball, 2006). Wayang is a solution to the lack of character education media. It is stated that wayang is a heritage from the ancestors filled with a set of moral values that can be taken as a great example for the students (Winarsih, 2014). Other than setting the exemplary characters in wayang characters as a good model, storytelling activity using wayang also helps to preserve Indonesian culture.

This research uses storytelling method by applying wayang. This method is chosen because it allows interactive communication between the storyteller and the kids. Storytelling is a preferable method than using a film or listening to it through CD because the storyteller could 
do a conscious action towards the listeners' reaction during the activity. Storytellers could also adjust themselves to the listeners' mood, or even drive the listeners' with the mood that the storyteller built (Eades, 2005). The children are able to convey their ideas when the activity occurs, so that they would feel involved, and could enjoy the story from beginning to end, different than films, comics, or a one-way story from audio. One-way methods are not likely to attract any response; the storyteller will have no chance to fix a possibly-wrong perception that the kids have towards the story's content.

Wayang kancil has existed since Kasunanan Giri (1478-1688) in Gresik. Kancil's character was created by Kanjeng Sunan Giri I, Raden Paku, one of Wali Sanga members, revered saints of Islam in Indonesia, to lift men's dignity, also as a hero of the nation. Until 2016, wayang kancil is still preserved by Ki Ledjar Soebroto who is also a wayang artist. He also became the dalang (wayang performer) who lives in Yogyakarta. Wayang kancil is made from leather, with animal characters and forest setting. The characters are kancil (mouse deer), tiger, elephant, crocodile, buffalo, monkey, and many others (Pursubaryanto, 2005; Pusat Data Wayang Indonesia, 2011).

Stories of wayang kancil performance come from stories that have been heard by generations in the community, as well as from previous puppeteers. In further developments, the puppeteers formulate their own stories, adapted to the issues that developed in the community at that time (Pursubaryanto, 2005). Therefore, the story in this study was developed by researchers with reference to the stories that have been there before. Wayang kancil performing technique has tried many times by puppeteer of wayang kancil Edy Pursubayanto since 1980. In 1995, Edy Pursubaryanto concluded that wayang kancil, especially with the audience of early age children, must also be as attractive as possible. Puppeteer must be able to "communicate" with the audience, the way that eliminates color and uses gamelan equipment to a minimum so that there is no distance between the puppeteers by the audience. A puppeteer can also be assisted by a nursery teacher, especially women, as the voice of hare figures. The nursery teacher can interact freely with the audience, so the audience seemed interested in enjoying the show until completion (Pursubaryanto, 2005). Based on the experience of previous puppeteers, it is concluded that wayang kancil can be presented in nursery students.

Eder (2010) explains that from all of the techniques of storytelling, tales about animals are the most special because, for so long time, animals have a major role to open the minds of the public about basic human values. The reason why people use animal characters, that human beings need a viewpoint outside of man himself before becoming a whole human being (Eder, 2010). Humans use animals also to divert the mistakes of himself.

\section{Research Method}

This research started with a preliminary study conducted by observation and interview with the targeted nursery school. The early interview and observation of eight nursery schools in Yogyakarta show that education regarding littering behavior to early age children has not been conducted.

This study is observing the littering behavior of children. The teaching effective character education is done by involving all aspects of cognition, emotion, and behavior in children. The approach used for imparting education in early childhood character who first is to give the concept of virtue in the form of knowledge, which in turn will be the attitude in the minds of 
children. The child's attitude can further develop into behavior through habituation in the child's daily life both at home and at school. Therefore, in this study, the researchers observed littering behavior using fairytale. Through stories, children will be given the knowledge of waste and then practice to reduce littering behavior in a short practice of littering behavior.

\subsection{Variable identification}

Purposive sampling was applied to select the respondent. The 14 early aged children, 8 boys, and 6 girls, from B group of a nursery school in Umbulharjo district, Yogyakarta were the subject of the study. The reason for group selection was the availability from the school and the children characteristic as inclusion criteria.

This study conducted on girls and boys aged 5-6 years old. Hasanah (2013) argues a very effective method is used to improve the character of children aged 5-6-year-old in nursery school. Winarsih (2014) study shows that children aged 5-6 years old were able to understand the story of a puppet that uses animal figures, but still considers that human life is different animals. Mattew (1984) suggests that children 6-year-old are able to understand the writings philosophical. Previously, Calvert (2007) argues that one of the methods that can be used to cultivate the children's ability to philosophize is a story about animals (fables). All respondents in this study should have never followed any psychoeducation program in the same theme. This criterion is an attempt to control the effect of behavioral changes that will occur is the result of giving treatment using wayang kancil storytelling.

Littering behavior in this study is the dependent variable. Littering behavior in early childhood is an activities done by early childhood included reducing and handling solid waste in form of disposing waste in its place and classify according to the type of waste, bring bottled drinks alone at the time of the school, and using waste paper to create a toy school (Wardani, 2015). Meanwhile, folktale using wayang kancil is an independent variable of this study. This media containing samples of littering behavior using animal-shaped puppet media, including mouse deer, elephants, tigers, buffalo, monkeys, crocodiles, and others. The stories contained in the fable wayang kancil used in this study contains a message or example of behavior and values related to waste disposal behavior: remove the waste in place and according to the type of waste, bring bottled drinks alone at the time of the school, and using waste paper to make toys in school. After each session, a fairytale ending will be followed by practicing the core of the story with certain activities. The research subjects will be invited to perform a simulation and are invited to take a lesson on the importance of solid waste disposal.

\subsection{Research instruments}

This study uses research eight instruments, i.e. wayang kancil, observation sheet, recording camera, trash bin, student's comprehension sheet on wayang kancil story, evaluation and observation sheet, evaluation sheet of psychoeducation implementation and student's comprehension test. Wayang kancil, module, and story script of littering behavior adapted from

Serat Kancil volume 1, 2, and 3 (Sasrawijaya, 1986) Wayang Kancil created by Ki Ledjar Subroto (Pursubaryanto, 2005), script of wayang kancil (Winarsih, 2014), littering behavior (Tarnoto, 2013) and the storyline follows the stages of the modeling process Bandura (1986), which consists of four processes: attention, retention, production, and motivation. 
An observation sheet of littering behavior on early age children was applied in this study. Observation sheet containing target observation of students in the class, date and time of the observation, the observer, the list of observed behavior which describes littering behaviors indicators of early childhood, as well as filling column observed during the observation period. The columns filled the charging observation result using a pillar. Meanwhile, the recording camera and tripod is applied to record the observation. The camera was placed in strategic places in order to record the process of observation at baseline measurements, interventions, as well reversal phase.

Two colors of trash bins, yellow and green, were used for the experiment. Yellow bins for inorganic waste, while the color green for organic waste. At baseline phase bins are not labeled organic/nonorganic, then the intervention phase trash bins labeled and images belonging to the organic/inorganic. After the intervention, the label and images on the trash are removed again.

The student's comprehension sheet on wayang kancil story is used in this observation to increase awareness of early age children to littering behavior. This sheet contains questions raised by the students when sub storyteller evaluation sessions. The answer will then be assessed by the observers by using yes and no answer.

Evaluation and observation sheet of wayang kancil storyteller to increase awareness of early age children to littering behavior. This sheet contains observer ratings of the verbal and nonverbal aspects of storytellers when carrying out the process of storytelling based on wayang kancil modules. Each aspect contains some items with scores range from 1 to 5 , where score 1 is very poor and 5 is very good.

Evaluation sheet psychoeducation program implementation of wayang kancil folktale to improve the awareness of early childhood to littering behavior. This contain items that assess the implementation process of intervention programs, ranging from the theme of fairy tales, timeline, the atmosphere, the completeness of the materials, the service/attitude of the organizers (researcher), tools, manner of presentation, material benefits, interaction with participants, and the use of tools/aids.

Student's comprehension test on littering behavior. Comprehension tests are presented with images that contain aspects of littering behavior (Tarnoto, 2013). Instruments such as the situation in the daily lives of preschoolers. Tests are presented at the end of the baseline measurement and at the end of the reversal measurement. Those tests were conducted to determine the difference in understanding the littering behavior of children before and after the intervention. The validity tool of this test has been made by Tarnoto (2013). The implementation of the test was by providing questions to subjects with picture illustrations. The answers will be scored 0 (zero) if the answer is not associated or deviated with behavioral indicators, 1 (one) if the answer is not quite right or the correct response is not accompanied by reasons, and two (2) in accordance with our behavioral indicators that are expected, along with the reason or solution behavior should be.

\subsection{Research design}

This research type is action research that implemented four stages of action research (Mertler, 2006). Those stages are planning, implementation, development, and reflection. 
Planning is implemented to find the problem, look for in accordance with the theoretical basis of the problem, and developing a research plan. The implementation or acting stage includes the implementation of interventions, retrieval, and analysis of data. The development stage is conducted to develop plans for further intervention. The last, the reflection stage includes the reflection of the research process and the delivery of research results.

The experimental research approach used to test the intervention's impact was A-B-A (Sarafino, 2005). ABA design has three phases: baseline (A), intervention (B), and reversal (A). ABA design refers to the condition's sequence from the experiment (Myers \& Hansen, 2002; Saville \& Buskist, 2005). A is a baseline condition, that is, a condition where participant's behavior is rated without any effect from the dependent variable. B is the experiment condition, that is, a condition where the dependent variable is given to see its effect upon subjects. When $B$ phase is done, A phase is repeated.

\subsection{Story intervention with wayang kancil as a medium}

The treatment that was given to the subject in this research is folktale storytelling using wayang kancil media as mentioned in the research instrument above. The story with wayang kancil was given out three times with three different stories. Stories in wayang kancil used in this study consisted of three headline stories. The third title describes the story of kancil and other animals that reflect the behavior of managing waste, including wasting bins in place according to its type, bringing bottled drinks at school, and using recycled paper when making toys at school. The previous study of Ahyani (2010) has proven that a tale contained moral education can improve early childhood moral intelligence and folktale using wayang kancil can increase prosocial behavior knowledge (Winarsih, 2014). According to Ahyani (2010) and Winarsih (2014), each story was effectively told for about 25-30 minutes for each title.

\section{Result}

This research uses wayang kancil folktale module adapted from wayang kancil module for prosocial attitude (Winarsih, 2014). Wayang kancil module for psychoeducation of littering behavior and the behavioral observation sheet have been validated through a content validation process. Professional judgment was applied for validation. The experts who validated this module consists of lecturers of Faculty of Psychology who were gathered doctoral degree, master/educational psychologist, and teachers of early childhood education. They rated each aspect of the module and observation sheet by giving a score on the scale of 1 to 5 . The researcher made improvements when the experts provided a low rate. The expert made a reevaluation of the module until it is eligible to be used for the study. The coefficient of the validity of the content has a score of 1.00. A good contribution to the objective measurement according to Cronbach is ranging from 0.30 to 0.50 (Azwar, 2013). Based on the Cronbach statement, the contents of the module and the observation sheet in this study are valid and can be used. The reliability of the use of the instrument in this study is the level of consistency and reliability were obtained from the records as Sarafino (2005) refers to Hayes (2000) and has been described in the research instrument. Results of inter-rater then processed and analyzed using statistical software of SPSS version 16 and produce Cronbach alpha about 0.971 . This indicates that the measuring instrument has high validity. 
According to Tarnoto (2013), solid waste disposal behavior of early age children consists of three aspects: littering the waste into the bin according to its type of waste, bringing their own drinking bottle to school, and using used paper to make crafts at school. Folktale with wayang kancil media is a folktale with littering behavior using wayang made into animal shapes such as kancil, elephant, tiger, buffalo, crocodile, and others. The story on wayang kancil used in this research includes value, behavior, and waste disposal behavior values that are arranged based on three solid waste management aspects. After the end of every folktale sessions, the storyteller invites the students to demonstrate the core message from wayang kancil folktale. The subjects were invited to perform stimulation from each aspect and to take the important lesson of solid waste management. The behavior recording in this research is conducted through an observation sheet.

Wayang kancil folktale is able to increase the awareness of waste disposal attitude on early age children. The result that showed the children engaged in the activities of solid waste disposal behavior will be described in graphic and statistical analysis. The analysis of the observation data presented in three methods: main data, per item data, and additional data analysis.

The data analysis of this research is to use graphic analysis results of behavioral observation and qualitative analysis of the score of the participant's comprehension score. The graphic analysis used to show the influence of the intervention. According to Sarafino (2005) the effect of intervention seen by comparing the value at baseline, intervention, and the reversal. Sarafino (2005) stated much behavioral analysis and behavioral therapy are focused on one person but can be used in setting the group which involves the observation of many people instead of just one or a few people. Likewise, the data will be aggregated and analyzed as a group instead of individually analyzes. Merging of data was conducted by calculating the average or the mean of all participants. Therefore, the unit of analysis in this study is a class that is a collection of individuals. Process analysis is performed against the target behavioral observations that arise during the process of observation in the classroom. Such behavior is the behavior of the group and not individual behavior. The whole graph analysis is supported by video, analysis of manipulation test result and interview results with the teacher.

Environmental behavior related to littering on group experiment is observed and analyzed by the five excessive and five deficit behavior. The ten behavior is determined based on the type of littering behavior by Tarnoto (2013). Excessive behavior is a behavior that is likely deemed as negative that its intensity should be decreased. Deficit behavior is a positive behavior with the rare occurrences that its intensity and frequency should be increased. The code and behavior that appeared in graph analysis refer to Table 1.

Based on the ten behaviors which were observed and analyzed from the above graph, it can be seen that there is a level difference that shows an increase of deficit behavior and a decline of excessive behavior in solid waste disposal on early aged children. The increasing deficit behaviors show that children's awareness is enhanced. So it is with the decreasing of excessive behavior. The littering behavior tendency graphs, other than being presented in groups, are also presented separately based on baseline, intervention, and reversal phase. 
Table 1. Code list and item type of littering behavior

\begin{tabular}{clc}
\hline \multicolumn{1}{c}{ Code } & \multicolumn{1}{c}{ Appeared behavior } & $\begin{array}{c}\text { Behavior } \\
\text { label }\end{array}$ \\
\hline Behavior 1 & Leaving the waste on the classroom floor & Excessive \\
Behavior 2 & Leaving food waste on classroom & Excessive \\
Behavior 3 & Putting the waste into the trash bin & Deficit \\
Behavior 4 & Putting the inorganic waste (no) to the trash bin labeled inorganic (no) & Deficit \\
Behavior 5 & Putting organic waste (o) to the trash bin labeled organic (o) & Deficit \\
Behavior 6 & Bring a refillable water bottle to school & Deficit \\
Behavior 7 & Bringing a single-use water bottle & Excessive \\
Behavior 8 & Making a craft with used paper & Deficit \\
Behavior 9 & Making a craft from a new paper & Excessive \\
Behavior 10 & Leaving the used paper on the floor & Excessive \\
\hline
\end{tabular}

\subsection{Solid waste disposal attitude probability graph}

By observing the graph shape of excessive and deficit behavior respectively on every phase, the changes and differences could be more realistically seen on each changing phase: preintervention (baseline), during treatment program (intervention), and when intervention is taken (reversal). Figure 1 consists of two graphs that depict excessive behaviors (top) and deficit behaviors (bottom). The graphs are started with baseline phase (up), intervention phase (middle), and reversal phase (down). The vertical line ( $y$-axis) of the graph shows the number of occurring acts as what has been explained on behavior code in Table 1, meanwhile the horizontal line ( $x$-axis) shows the type of behavior.

Figure 1 (top) shows that the number of excessive behaviors is decreased to zero in the intervention phase. Meanwhile, the deficit behavior in Figure 1 (bottom) shows the increase in all types of deficit behavior during and after the intervention phase. The excessive behaviors of children on making a craft from a new paper were 24. It is higher than the behavior of children who made a toy from paper waste (it was 4). Meanwhile, children's behavior to bring single-use bottles to school (behavior 7) were few because the teacher gave the advice to tidy up goods including food waste after the activity. In the positive behavioral, the behavior of putting the rubbish in the bin in the baseline was 36 and this behavior improved after the intervention. However, initially, the children were unable to put separate inorganic and organic waste (behavior 5 and 6). Meanwhile, the behavior of 4, 5, and 6 in the baseline were 0 (zero) because students do not have knowledge about those behaviors.

In the intervention phase, the decrease of excessive behaviors is apparent except the behavior of children who leave the rubbish on the floor (behavior 1). However, there were rocketed of deficit behaviors (Figure 1 bottom) except the behavior to rubbish in the bin. The significant increase of separating organic and inorganic waste (behavior 4 and 5) occurs because that is new information that led children more enthusiastic to separate organic and inorganic waste into different bins.

Interestingly, there was an increase in all excessive behaviors during the reversal phase. There were slightly increased during reversal phase of children behavior in terms of leaving the 


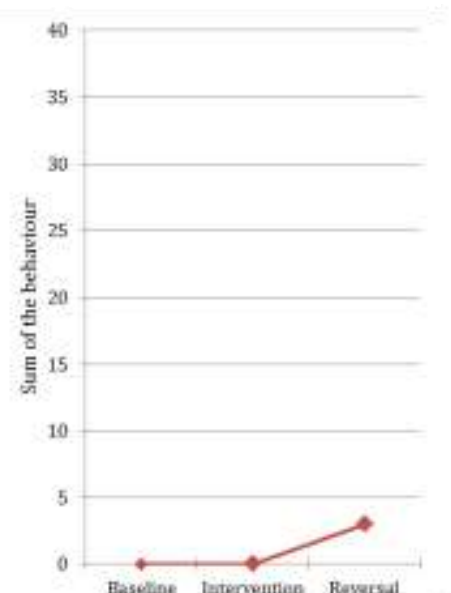

Behavior 1

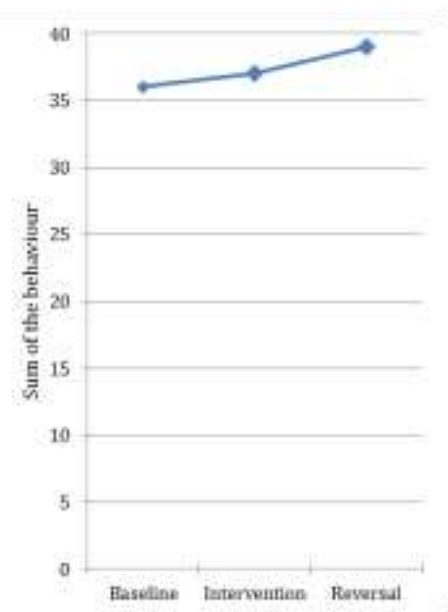

Behavior 3

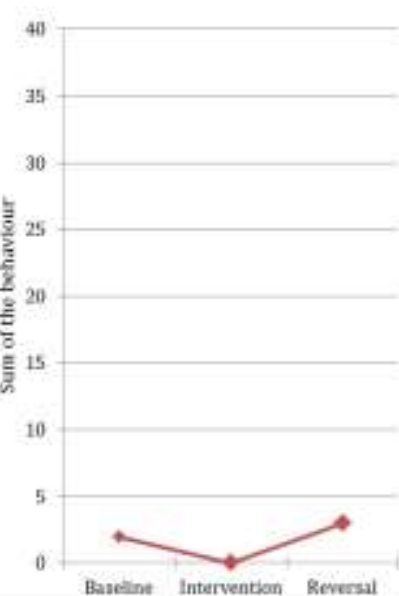

Behavior 2

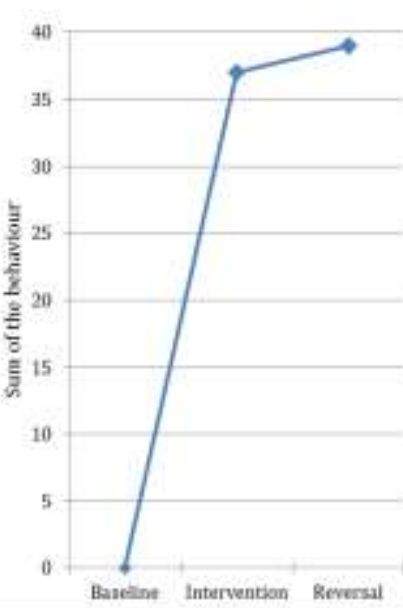

Behavior 4

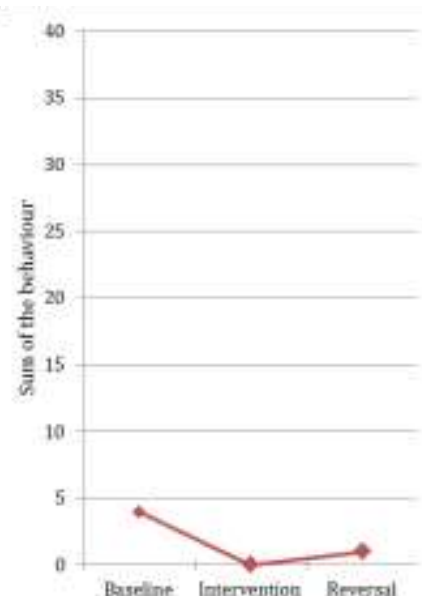

Behavior 7

(a)

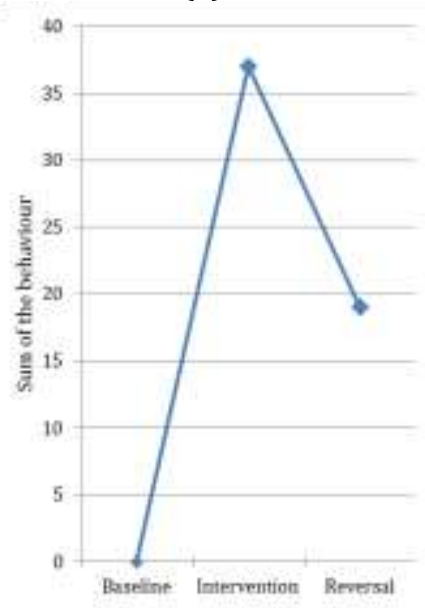

Behavior 5

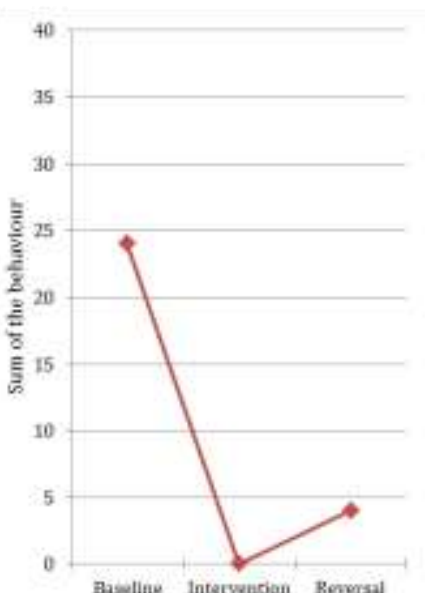

Behavior 9

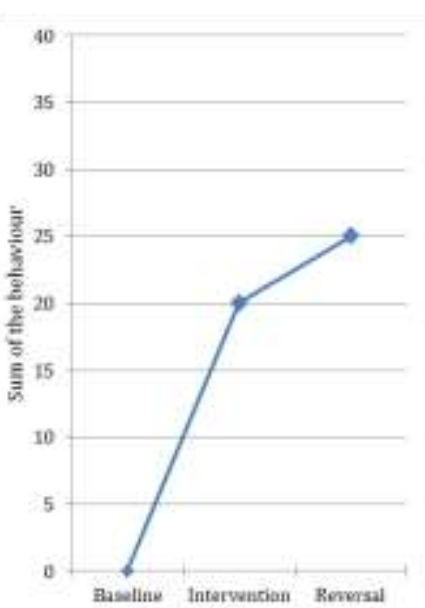

Behavior 6

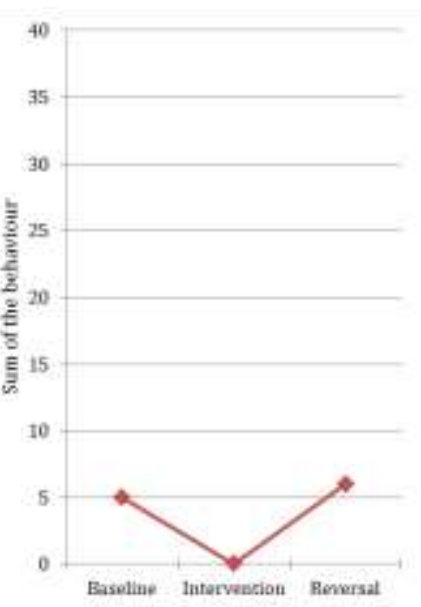

Behavior 10

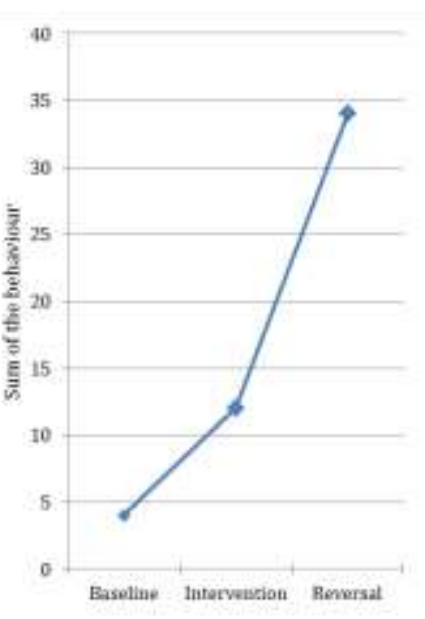

Behavior 8

Figure 1. Baseline-intervention-reversal phase graphs of excessive behaviors (top) and deficit behaviors (bottom). The excessive behaviors contain behavior number 1 (leave the rubbish on the floor), 2 (leave the food waste in the classroom), 7 (bring a single-use water bottle), 9 (made a craft from new paper) and 10 (leave the paper waste on the floor). Meanwhile, the deficit behaviors refers to behavior number 3 (Put the rubbish in the bin), 4 (put inorganic waste in inorganic bin), 5 (put organic waste in the organics bin), 6 (bring refillable water bottle to the school), and 8 (made a craft from used paper) 
rubbish on the floor (behavior 1), leaving the food waste in the classroom (behavior 2), bring single water to the school (behavior 7) and made crafts from new paper (behavior 9). Meanwhile, there was increased more than 5 in the behavior of children of leaving paper waste on the floor. These occurred when students practiced cutting, pasting and drawing. Many papers remaining in class despite observation, they have thrown in the trash. These have been proven from the deficit behavior (Figure 1, bottom) in putting the rubbish in the bin (behavior 3) which rose as much as 3 behaviors from 36 to 39 during the reversal phase. In the meantime, the behavior of putting inorganic waste to the inorganic bin (behavior 4) and bring a refillable water bottle to school (behavior 6) have also increased during the reversal phase. The rocketed improvement during the reversal phase occurred for the behavior of children in making crafts from used paper. However, there was a reduction behavior of children in putting organic waste in the organics bin during the reversal phase.

The most significant changes in the number of behaviors that appear either increase or decrease to behavioral deficits in excessive behavior show the influence of the intervention. The presence of excessive behavior that increases in the phase reversal or behavioral deficit declining course there is certain reasons that can be explained on a per-item analysis.

\subsection{Single behavior data analysis}

The analysis of data as the result of the study also conducted at every observed behavior. Analysis of data per item uses graphic analysis/visual inspection and qualitative analysis of the results of the solid waste disposal of behavioral interventions in early childhood using wayang kancil folktale. Visual inspection techniques used to demonstrate the effect of the intervention through experiments that include covering the behavior of discarding waste sorting, bring a bottle of liquor to school, and utilizing waste paper. The following 10 items analysis of three aspects of littering behavior. The tenth item in the item analysis below as a sequence in the code table and grouping behavior (Table 2). The result of the sum of behaviors is depicted in Figure 2 and Figure 3. Meanwhile, descriptions of analysis per item are described in the following paragraphs.

\subsubsection{Excessive behavior}

\section{Behavior 1: Leave the waste on the classroom floor (Excessive)}

Based on observations during the nine meetings, it is appeared the increased littering behavior in the classroom floor (Figure 2.a) in days seventh and eighth. On the first day until the sixth no visible behavior of littering. But in the seventh and eighth are littering behavior on the classroom floor. No littering behavior until day sixth is because during the baseline period (days $1^{\text {st }}-3^{\text {rd }}$ ) and intervention (day $4^{\text {th }}-6^{\text {th }}$ ) teachers always remind students to pick up the rest of the craft or leftover food wrappers. However, during the reversal phase (day $7^{\text {th }}{ }^{\text {th }}$ ) the teachers were changed and they did not remind students to dispose of the waste in the bin. In addition, the increase in littering behavior by students is because they forgot.

\section{Behavior 2: Leaving food waste in the classroom (Excessive)}

The trend of the behavior of students on leaving food waste in the classroom for nine days is depicted in Figure 2.b. In the baseline period, in day $1^{\text {st }}$ and $2^{\text {nd }}$, littering food waste was apparent. But, it reduced during the intervention period. Unfortunately, littering food waste increased on day $7^{\text {th }}$ and $8^{\text {th }}$. The reason for the rebound of this behavior in the reversal period 
because the children did not get a reminder from the teachers. When the food is served on the eve of the break make teachers more difficult to control the students who leave food on the floor.

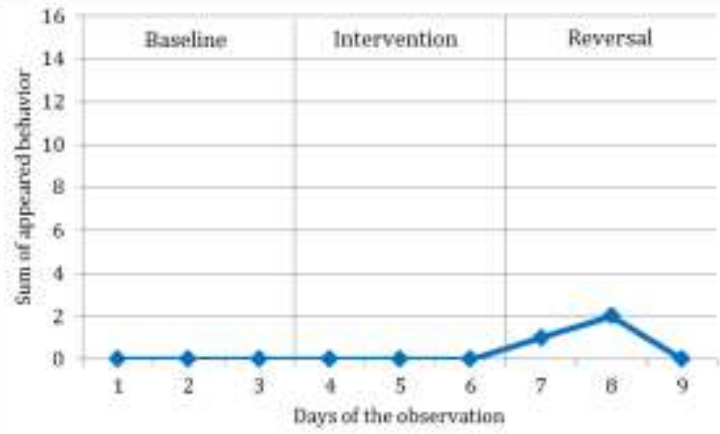

(a)

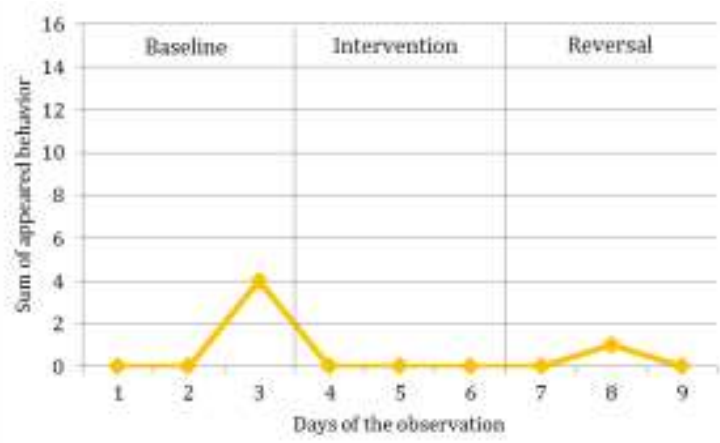

(c)

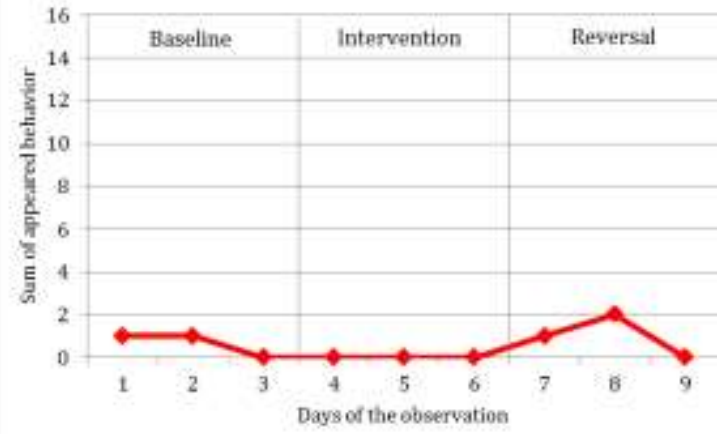

(b)

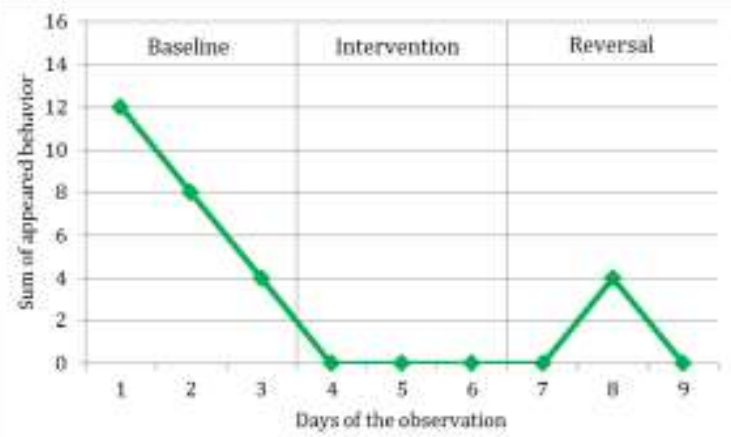

(d)

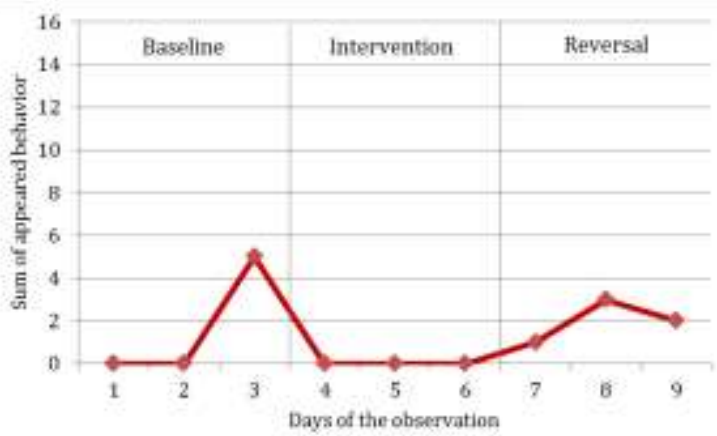

(e)

Figure 2. Single behavior analysis of excessive behaviors. (a) Behavior 1, (b) Behavior 2, (c) Behavior 7 , (d) Behavior 9 and (e) Behavior 10.

\section{Behavior 7: Bringing a single-use water bottle (Excessive)}

The result of nine days of behavior observation related to children's behavior on bringing a single-use water bottle is depicted in Figure 2.c. It is apparent the decline of this behavior during the intervention period, even though it rebound to slightly increased in day $8^{\text {th }}$ and $9^{\text {th }}$. In the initial period, there were some kids bring a single-use water bottle to school. This is because 
they did not know the negative effect of using a single bottle and a plastic bottle. After they were given a knowledge of the negative effect of a single-use water bottle, no kids with a single water bottle from day $4^{\text {th }}$ to day $7^{\text {th }}$. Some of the students brought a plastic bottle to the school but it was refilled. So, the waste from the plastic bottle could be postponed.

\section{Behavior 9: Making a craft from new paper (Excessive)}

The next excessive behavior is making a craft from new papers. The result of the observation of this behavior is depicted in Figure 2.d. It was apparent that in the initial period, more students (12 pupils) used new paper for making crafts. After they were given knowledge that making crafts from new paper increased waste, it then plummeted significantly to zero students during the intervention period. However, in the reversal period, there were a small number of children remained to use new paper for making a craft.

\section{Behavior 10: Leaving used paper on the floor (Excessive)}

The trend of behavior in leaving used paper on the floor is almost similar to the behavior of students in bringing single-use water bottles to the school (see Figure 2.e). At the baseline period, some students unaware of used paper that fell to the floor. After the team did an intervention to them, there was no leaving used paper on the floor anymore. However, when the time reserved back there were some children who left the waste paper in the classroom. This indicates that during littering behavior training, the reminder from a teacher of the research team is needed because children did not aware of this behavior.

\subsubsection{Deficit behavior}

\section{Behavior 3: Put the rubbish into the trash bin (Deficit)}

At the initial activity, during the baseline period in the first three days, there were 12 children have put the rubbish in the bin. It then increased to 14 on day $5^{\text {th }}$ and remained fluctuated between 12 and 14 children until the reversal period. This happened because prior to this research, students are accustomed to collecting garbage snacks after meals. Nevertheless, there are still students did not dispose of waste in the bin. However, after the intervention of the students become more motivated to dispose of waste in the bin. Students were also informed of the reason they must dispose of waste in place, not only because of the suggestion of a teacher.

\section{Behavior 4: Putting on-organic waste (no) to the trash bin labeled inorganic (no) (Deficit)}

At the intervention period, the activity of children who put the inorganic waste in the inorganic bin lifted considerably (see Figure 3.b). At the time of implementation of the baseline period, no children did the right in putting the inorganic waste. At the baseline period, the children did not receive the knowledge to separate organic and inorganic waste into different bins. Evidently, after the intervention, it is apparent the changes to separate waste into different bins. This indicates that knowledge of waste separation may influence children's behavior.

Behavior 5: Putting organic waste (O) to the trash bin labeled organic (O) (Deficit)

Similarly to the behavior of putting inorganic waste to inorganic waste, children's behavior on putting organic waste in organic waste during the baseline period was zero (see Figure 3.c). During the intervention period, day fourth today sixth, there was significantly improved in the number of children who put the organic waste into the organics bin. However, the declined was 
happen during the reversal period, day seventh today ninth. This occurred because more students did eat all of the food provided by the researcher. The rest of the food was partly taken home by students.

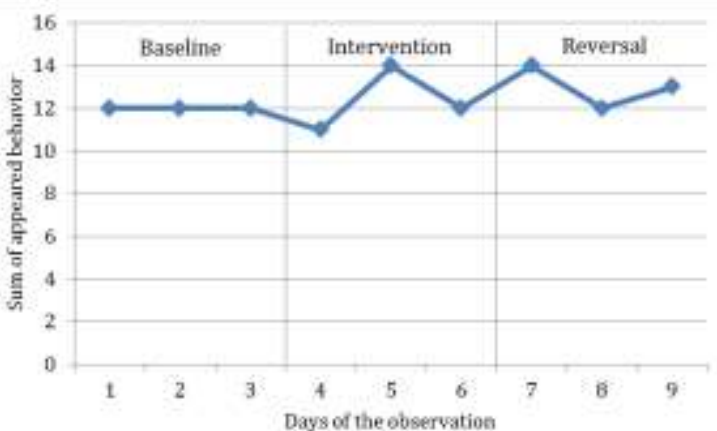

(a)

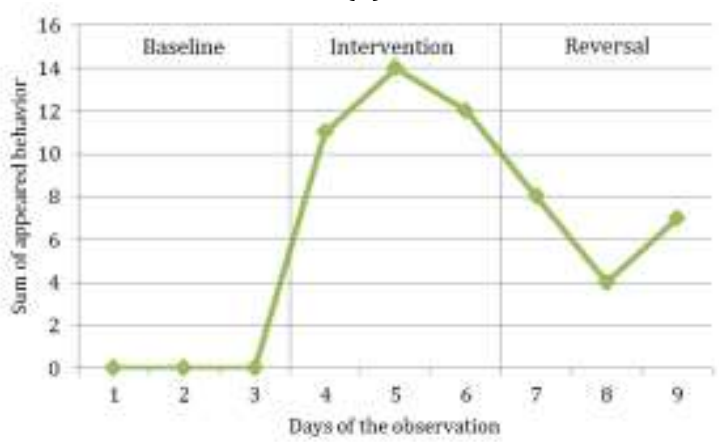

(c)

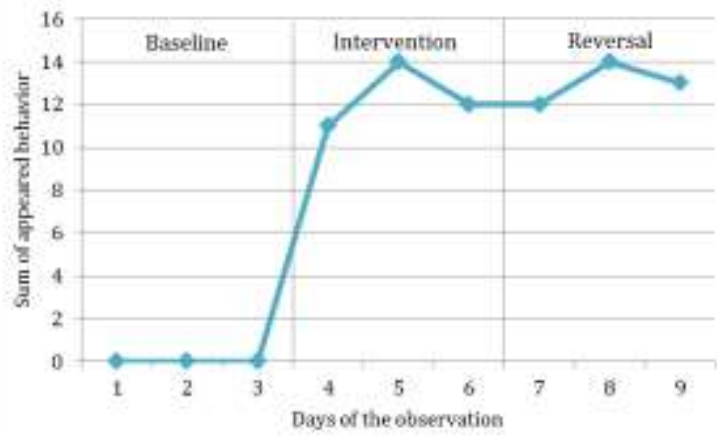

(b)

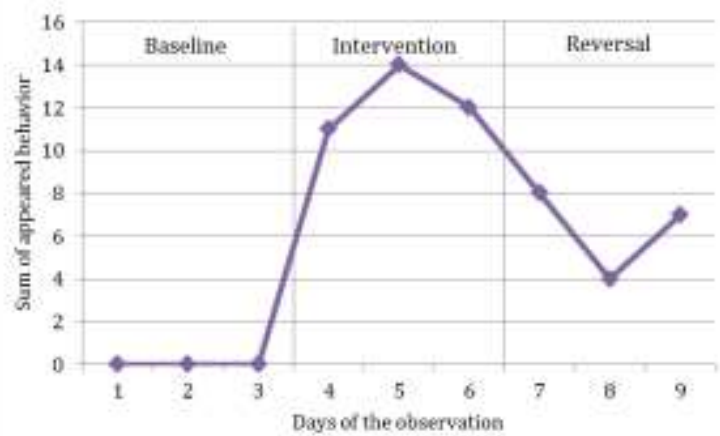

(d)

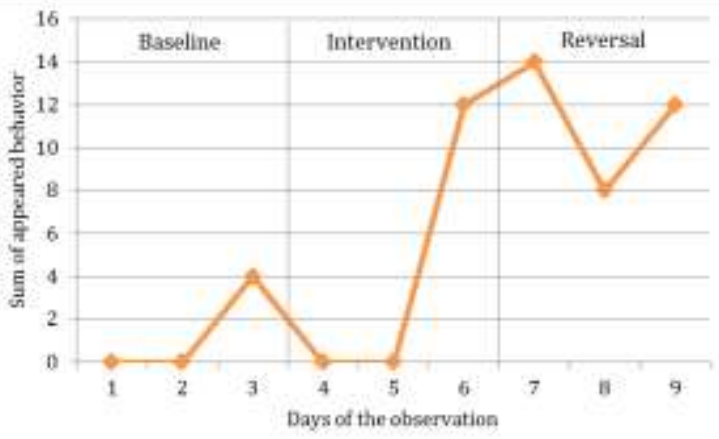

(e)

Figure 3. Single behavior analysis of deficit behavior. (a) Behavior 3, (b) Behavior 4, (c) Behavior 5, (d) Behavior 6 and (e) Behavior 8

Behavior 6: Bring a refillable water bottle to school (Deficit)

The trend of the behavior of a student brings in a refilled water bottle is similar to the behavior of a student in putting the organic waste into organic bins, as seen in Figure 3.d. During the intervention period, a number of students who bring refiled water bottles reached the highest. It got down to 4 children on day $8^{\text {th }}$. Knowledge about the dangers of water plastic bottles to the environment was given to the children during the intervention period. This 
increasing number of children who bring a refiled water bottle to the school. But, eating the reversal period, the number of children who bring refiled water bottle reduced significantly.

\section{Behavior 8: Making a craft from used paper (Deficit)}

The trend of the behavior of children to make a craft from used paper as depicted in Figure 3.e. There was an absence of students who made crafts from paper waste in day fourth and fifth. But, it is apparently seen that the increase in a student who uses used paper for making craft increased significantly in day sixth and seventh. The knowledge given to children during the intervention period did not directly influence children's behavior in the day fourth and fifth. But it affected children in day sixth and seventh

In this study, it was observed that the increase in deficit behavior and the decline in excessive behavior may persist after the intervention. It was caused by the role of teachers who provided a reminder for students. In addition, in some cases, children have been able to do it without a reminder from the teacher.

\subsection{Additional data analysis (the manipulation check)}

Additional analysis in this research is conducted on data obtained from the manipulation checks as already mentioned at the end of the study procedure. Check manipulation is part of the procedure that is useful to ensure or strengthen the validity of the data. Table 2 provides the results of all three forms of checks manipulation.

Table 2. Statistical test results Paired Sample Test 1, 2, and 3

\begin{tabular}{|c|c|c|c|c|c|c|}
\hline Paired sample & Mean & St. Dev & Std. Error Mean & $\mathrm{t}$ & $\mathrm{df}$ & $\begin{array}{c}\text { Sig- } \\
\text { value }\end{array}$ \\
\hline $\begin{array}{l}\text { Test 1: } \\
\text { Throw and sorting the waste } \\
\text { (Pre-post intervention) }\end{array}$ & -1.90 & 0.316 & 0.100 & -19.00 & 9 & 0.000 \\
\hline $\begin{array}{l}\text { Test 2: } \\
\text { Bring water bottle } \\
\text { (Pre-post intervention) }\end{array}$ & -1.40 & 0.699 & 0.221 & -6.332 & 9 & 0.000 \\
\hline $\begin{array}{l}\text { Test 3: } \\
\text { Paper waste reuse } \\
\text { (Pre-post intervention) }\end{array}$ & -1.90 & 0.316 & 0.100 & -19.00 & 9 & 0.000 \\
\hline
\end{tabular}

\subsubsection{Participants' understanding of the test results before and after the intervention}

Statistical analysis using paired samples test showed significant gains in the third item of knowledge about the behavior of throwing understanding and sorting the waste, bring water bottles to school, as well as using waste paper to make toys. The following analysis of the results of a statistical test using the Paired Sample Test.

Based on the statistical test provided in Table 2, the paired sample test for Test 1 has proven that there is no significant difference in students' knowledge about the behavior of 
littering, especially before and after the intervention. The difference indicated by the value of $t$ which is equal to -19.00 . This study uses the critical value of $t$ equal to 2.56. Meanwhile, a $p$ value of Test 1 in Table 2 is 0.000 . The greater of $t$ in comparison to the critical value of $t$ or the smaller $p$-value in comparison critical value of $\alpha$ indicates the rejection of the hypothesis. When the null hypothesis says that it is no difference between pre and post-intervention, the smaller $p$ value than $\alpha$ (which is equal to 0.01) means that the hypothesis is rejected. This implies that the intervention to children's environmental behavior by using wayang kancil folktale was significant. P-value of Test 2 and Test 3 also show the value of 0.000 . This means that the data from this study have proven that wayang kancil intervention has influenced children's behavior to bring a refilled water bottle and use paper waste.

Statistical test results are very significant to check the results of the three aspects of management manipulation trash fairy tale puppet prove that deer can increase knowledge about littering behavior in early childhood. Knowledge is the basis of the formation of the child's behavior.

The results of an assessment of the implementation of the module to research conducted by storytellers. The results of the analysis score storyteller are divided into 2 parts namely a score of verbal and nonverbal. An assessment of verbal ability and nonverbal storyteller each earn an average score of 4.8 (scale of 5) who means well. Storyteller-item verbal skills include:

a. Explaining the theme of which will be delivered (no opening words)

b. Conveying the material with the right choice of words and attractive to children,

c. Deliver material with an easily understood explanation,

d. Clarify (repetition explanation) to be accepted and remembered students,

e. Giving examples of positive practices in fairy tales,

f. Invites students to interact or talk in a fairy tale,

g. Motivating students to undertake waste disposal as exemplified in fairy tales, and

h. Using visual media in explaining the material.

i. While the storyteller nonverbal item includes:

j. Eye contact (attention) all participants,

k. Proper body movement in order to attract the attention of students as storytelling,

l. Facial expressions adapted to the material being conveyed,

$\mathrm{m}$. Low high emphasis voice when explaining the material adapted to the conditions,

n. Issued storyteller voice easily heard by the audience,

o. Having enthusiastic when presenting the material, and

p. Using humor in presenting the material.

\subsubsection{An assessment of the implementation process of the research program in general}

Analysis of experimental data evaluation of the intervention program strengthens the research results with an average value of 4.7 which also means good. The implementation of the evaluation item includes the theme of training, timekeeping, the atmosphere, the completeness of the materials, and the service/attitude of the organizers, tools, and manner of presentation, material benefits, and interaction with participants and the use of tools. 


\subsection{Discussion}

This study aims to determine whether the use of media such as Wayang Kancil Folktale is able to reduce littering behavior in early childhood that marked by their engagement on the activities of waste disposal behavior. The results showed the behavioral changes in this study after the intervention. Changes in behavior that occurred after the intervention was due to new knowledge and skills that are taught on the research participant. Knowledge and skills that intended are environmental awareness education, especially regarding littering behavior. In line with the opinions Kos et al. (2016) that the establishment of a caring attitude through the education environment more effectively applied to a younger age (early childhood) and become less effective and difficult to be implemented in line with age.

Through wayang kancil folktale psychoeducation, teachers can deliver environment awareness education through an interactive method and the corresponding development of the child. The method has the advantage that the other fairy tales, which allows storytellers to be responsive to the listener (Eades, 2005). Storytellers can adjust to the mood of the listener, directed listeners corresponding desired mood storytellers, including the storyteller, can provide corrections to reactions that are false or erroneous participants' understanding of the content of a fairy tale. During this process of education about hygiene, especially more debris carried by refraction in the form of verbal encouragement.

Based on the process of implementation in the field, look at how storytellers convey messages and stories that add to the vocabulary of the new information for research subjects. Storytellers also evaluated understanding the information that has been submitted to the session's beforehand fairy tale. If students have any errors in understanding the message or students forget, the storyteller will be corrected and recalls. This is in line with the opinion of Bishop and Kimball (2006), which states that students are easier to learn and recall of a knowledge that is delivered through a fairy tale, rather than knowledge delivered in a way that is informative.

This observation aims to determine whether folk tale using wayang kancil media could increase the awareness of solid waste disposal behavior on early age children. The result shows a change of behavior on the research's subjects after the intervention is being done. Corresponding to Kos et al. (2016) opinion, environment-awareness behavior shaping through education is more effectively applied to children of a younger age. It gets less effective and harder to implement as they get older.

The observation result shows that there is a significant littering behavior on research subjects after the intervention is applied. The external influence could affect individual behavior through cognitive processes. Bandura's social cognitive theory (in Eisenberg \& Mussen, 2003) explains that cognitive process plays an essential role in human's change of behavior. This change in the research's subject could be realistically seen in terms of sorting waste and taking advantage of used paper. All this time, subjects have never been familiar with the concept of waste sorting-out thus they never implement it. After the intervention process is being conducted, students could sort out and differentiate between organic and inorganic waste. Other than that, a student could also be able to explain the reason why they chose to use paper to make toys/toys or the reason for bringing a drinking bottle to school. This result is strengthened by the result of students' comprehension test scores towards the trash management aspect that 
shows the significant score on each indicator. Paired Samples Test result on pre and post score on littering and sorting out waste, bringing drinking bottle to school, and using used paper to make toys indicators consecutively.

Jean Piaget (Monks et al., 2001) explains stated that the cognitive skills of children aged 56 years old are different from cognitive skills during the pre-operational phase. Children during this phase could imitate acts that they see, even acts that they had seen a day before (delayed imitation). However, children still require help in the form of a tool or real experience in order to comprehend abstract concepts. Jean Piaget's opinion corresponds to the subject criteria of this research. Subjects of this research are early aged children aged 5-6 years old. Therefore, cognitively, they could imitate exemplary acts shown by wayang kancil folk tale.

Other than the subjects' age factor, early age children's behavior is also influenced by the pattern of how a family raises them. If observed from the family's background, the subject of this research would come from many different backgrounds, whether it is the economic or educational background. Generally speaking, most families come from lower-intermediate* economic conditions. The family background becomes one of the topics in this discussion because based on the previous research about waste-littering attitude (Iskandar, 2009; Yulida, 2015) educational factors could be related to waste littering behavior on society. The other factor is the environmental condition around the subject's residence, whether it is in a densely or sparsely populated area.

The population density factor also does not become an inclusion requirement of this observation. Iskandar (2009) shows that educational factors and income are proven as a positive impact on the population's behavior in waste littering. Meanwhile, occupation and family member's numbers are not proven to have any correlation to it. Yulida et al. (2016) reveal a connection between knowledge attitude regarding waste littering behavior that it is considered as important to give information and counseling to society about the healthy and correct way to manage waste. In this research, the process of information giving and society education is conducted through school, that is, on early childhood education.

Wayang kancil folk tale is expected to be an alternative education on maintaining environments' hygiene as it is one of an essential issue to be taught to children from an early age. The awareness of keeping hygiene is one of the things that parents always taught to their toddler children by teaching them about urination and defecation, also known as potty training. Nurfajriyani et al. (2016) explained that potty training is a necessary skill acquisition so that they can urinate and defecate in the toilet at the right time and in the right way that will be socially accepted. In a way, it can be concluded that potty training on a toddler is one of the hygiene-life training. Thus, when they enter school age, the children will be faced with a more complex situation of environmental sanitation, and one of them is keeping the surrounding environment clean from waste. Therefore, the intervention process conducted at a nursery school is also one of the parts of keeping the environment clean.

The teaching process could be performed by giving examples, and thus the teachers become their role models. Intervention result using wayang kancil model is proven effective by using Bandura's modeling principal so that the teachers are also expected to follow along the behavior-changing step using the modeling principle. In this case, teachers become real evidence 
of maintaining the behavior that has been learned during the intervention session. Bandura (1986) explains that the modeling process consists of four steps, those are attention, retention, production, and motivation. On the attention step, a child will observe the model that they consider as interesting as the way the model dress, speak and act. Next, the information that they perceive is recorded into their memories in the form of symbolic codes. This step is called the retention process. Through symbolic media, a brief experience could be kept in permanent memory. The next step is the production step, that is, the alteration of the symbolic concept into a matching behavior from the model. The last step is motivation, in which a child feels motivated to spark some act similar to the model that they are observing from before.

This research has some of its limitations, and one of them is, there is no follow up or structured measurement after reversal measurement. The observer only conducted an interview with the class' representative teacher about the continuity of this educational program at the end of the reversal session and one week after the observation is done. The teacher told the Observer that the program that has been conducted gives huge benefits for the school and the teacher also implied that they want to keep this program going, even without observers.

The entirety of the process that observer has done since doing a preliminary study on the field until the writing of this research is a part of the action research method that implements four steps like Mertler (2006) and those are planning, acting stage, developing stage, and reflection stage. The experiment design in this research refers to Sarafino's (2005) experiment condition using the A-B-A formula (baseline-intervention-baseline/reversal). In the next research, an improvement could be done by doing A-B-A-B design (baseline-interventionbaseline/reversal/intervention) in order for researchers to observe clearly the dynamics of behavioral changed that happened because of intervention through folk tale using wayang kancil.

\section{Conclusion}

The result of this observation proves that wayang kancil folk tale could increase the awareness of waste disposal behavior on early aged children (decreasing the excessive behavior and increasing the deficit behavior). The analysis result proves that there is a significant difference in the littering behavior items on the baseline phase compared to the intervention and reversal phase. However, the result of this research's weakness is on the continuation of intervention result that has been conducted at school. Therefore, here are the observer's advice to the school and to the upcoming observers.

The school is advised to take advantage of wayang kancil folk tale psychoeducation program as an interesting learning method and use psychology principals such as Bandura modeling. Moreover, the program could be integrated with another school program as a preventive effort and overcome the act of littering or unhealthy food-buying. The teacher holds the main role in maintaining the previously shaped behavior in the intervention process, so teachers are expected to also give a better model in waste disposal behavior and taking advantage of a previously made module by the observer to teach waste disposal behavior to other students that have never received similar psychoeducation program.

The future observer is advised to do a re-observation, but with different object situations, for example, for the first-year student of the nursery. To the observers that have an interest in 
doing behavior research using observation, they are advised to conduct a baseline measurement for a longer period to be sure of the behavior's consistency. Waste disposal behavior is an overt behavior and makes it easy to observe. However, in the observation, more experiments should be involved to control external variables that could affect observation results. The next observer is advised to adjust their observation schedule so that the observation process could be conducted more optimally.

\section{References}

Ahyani, L. . (2010). Metode dongeng dalam meningkatkan perkembangan kecerdasan moral anak usia prasekolah. Universitas Gadjah Mada.

Aini, M., \& Laily, P. (2010). Preparedness of Malaysian pre-school educators for environmental education. Pertanika Journal of Social Sciences \& Humanities, 18(2), 271-283.

Ananth, A. P., Prashanthini, V., \& Visvanathan, C. (2010). Healthcare waste management in Asia. Waste Management, 30(1), 154-161.

Azwar, S. (2013). Validitas dan Reliabilitas. Yogyakarta: Pustaka Pelajar.

Bandura, A. (1986). Social foundations of though and action: A social cognitive theory. New Jersey: Prentice-Hall International, Inc.

Basile, C. G. (2000). Environmental education as a catalyst for transfer of learning in young children. The Journal of Environmental Education, 32(1), 21-27.

Bierhoff, H. W. (2001). Responsibility and Altruism: The Role of Volunterism. In A. E. Auhagn \& H. W. B. Hoff (Eds.), Responsibility-theMany Faces of a Phenomenon-(pp. 149-166). London: Routledge.

Bishop, K., \& Kimball, M. A. (2006). Engaging students in storytelling. Teacher Librarian, 33(4), 28-31.

Boyle, L. (2006). Environmental experiences in child care. The Newsletter of the National Childcare Accreditation Council (NCAC), 19, 14-17.

Bredekamp, S., \& Copple, C. (1997). Developmentally appropriate practice in early childhood programs serving children from birth through age 8. 1509 16th Street, NW, Washington, DC 20036-1426: National Association for the Education of Young Children.

Calvert, K. (2007). Creative philosophizing with children. Theory and Research in Education, 5(3), 309-327.

Darmono. (2010). Lingkungan hidup dan pencemaran, hubungannya dengan toksikologi senyawa logam. Jakarta: UI Press.

DeRosier, M. E., \& Mercer, S. H. (2007). Improving student social behavior. The effectiveness of a storytelling-based character education program. Journal of Research in Character Education, 5(2), 131-148.

Derraik, J. G. . (2002). The pollution of the marine environment by plastic debris : a review. Marine Pollution Bulletin, 44(9), 842-852. http://doi.org/https://doi.org/10.1016/S0025326X(02)00220-5 
Eades, J. (2005). Classroom tales: Using storytelling to build emotional, social and academic skills across the primary curriculum. London: Jessica Kingsley Publishers.

Eder, D. (2010). Life lessons through storytelling: Children's exploration of ethics. Indiana: Indiana University Press.

Edwards, L. C. (2009). African American Storytelling: Collective Memory, Creative Resistance, and Personal Transformation. Retrieved from https://pqdtopen.proquest.com/doc/305169952.html?FMT=AI

Eisenberg, N., \& Mussen, P. H. (2003). The roots of prosocial behavior in children. Cambridge: Cambridge University Press.

Ertürk, G. K., Hande, E., \& Aydın, Ö. (2015). Changing Preschool Children's Attitudes into Behavior towards Selected Environmental Issues: An Action Research Study. International Journal of Education in Mathematics, Science and Technology, 3(1), 46-63.

Flogaitis, E., Daskolia, M., \& Liarakou, G. (2005). Greek kindergarten teachers practice in environmental education: an exploratory study. Journal of Early Childhood Research, 3(3), 299-320.

Frude, N., \& Killick, S. (2011). Family storytelling and the attachment relationship. Psychodynamic Practice, 17(4), 441-455.

Goncharova, M. (2012). Planet play :, (May), 329-334.

Green, D.S., Boots B., Blockley, D.J., Rocha, C., R. T. (2015). Impacts of Discarded Plastic Bags on Marine Assemblages and Ecosystem Functioning. Environmental Science \& Technology, 49(9), 5380-5389.

Hasanah, S. P. (2013). Pengaruh Metode Bercerita Terhadapkarakter Anak Usia 5-6 Tahun Di TK FKIP UNRI Pekanbaru. Universitas Riau.

Hayes, N. (2000). Doing Psychological Research: Gathering And Analyzing Data. Philadelphia: Open University Press.

Hetherington, E. M., Parke, R. D., \& Locke, V. O. (1999). Child psychology: A contemporary viewpoint. Tokyo: McGraw-Hill.

Ibrahim, A. N., \& Asmawi, M. Z. (2012). The level of awareness towards environmental issues and concern among students in tertiary level: Case study of universities students in Kuala Lumpur and Klang Valley of Malaysia. APSA Congress 2011, 10.

Iskandar, D. (2009). Kajian lingkungan kultural terhadap persepsi, sikap dan perilaku penduduk dalam membuang sampah di perkotaan Kecamatan Rengat Kabupaten Indragiri Hulu Propinsi Riau. Universitas Gadjah Mada.

Jambeck, J. R., Geyer, R., Wilcox, C., Siegler, T. R., Perryman, M., Andrady, A., ... Law, K. L. (2015). Plastic waste inputs from land into the ocean. Science, 347(6223), 768-771. Retrieved from https://science.sciencemag.org/content/347/6223/768

Kahriman-Ozturk, D., Olgan, R., \& Guler, T. (2012). Preschool children's ideas on sustainable development: How preschool children perceive three pillars of sustainability with the regard to 7R. Educational Sciences: Theory and Practice, 12(4), 2987-2995. 
Karpudewan, M., Ismail, Z., \& Mohamed, N. (2013). PRE-SERVICE TEACHERS â€TM UNDERSTANDING AND AWARENESS OF SUSTAINABLE DEVELOPMENT CONCEPTS, 28, 117-130.

Kementerian Pendidikan dan Kebudayaan. (2012). Pedoman pendidikan karakter pada anak usia dini. Jakarta: Direktorat Jenderal Pendidikan Anak Usia Dini, Kementerian Pendidikan dan Kebudayaan.

Kiswanto, E., \& Pitoyo, A. J. (2016). Policy brief indeks perilaku peduli lingkungan di Yogyakarta: Potret rendahnya kepedulian masyarakat terhadap lingkungan. Yogyakarta.

Kofoworola, O. F., \& Gheewala, S. H. (2009). Estimation of construction waste generation and management in Thailand. Waste Management, 29(2), 731-738. http://doi.org/https://doi.org/10.1016/j.wasman.2008.07.004

Kos, M., Jerman, J., Anžlovar, U., \& Torkar, G. (2016). Preschool Children's Understanding of ProEnvironmental Behaviours: Is It Too Hard for Them? International Journal of Environmental \& Science Education, 11(12), 5554-5571.

Mattew, G. B. (1984). Dialogues with Children. Cambridge, Massachussetts: Harvard University Press.

Meiboudi, H., Karimzadegan, H., Mohammad, S., \& Khalilnejad, R. (2011). Social and Enhancing children 's environmental awareness in kindergarten of Mashhad city using mural painting. http://doi.org/10.1016/j.sbspro.2011.11.187

Mertler, C. A. (2006). Action Research: Teacher as Researchers in the Classroom. London: SAGE Publications.

Monks, F. J., Knoers, A. M. P., \& Hadinoto, S. R. (2001). Psikologi perkembangan: Pengantar dalam berbagai bagiannya. Yogyakarta: Gadjah Mada University Press.

Musser, L. M., \& Diamond, K. E. (1999). The children's attitudes toward the environment scale for preschool children. The Journal of Environmental Education, 30(2), 23-30.

Myers, A., \& Hansen, C. H. (2002). Experimental psychology (5-th editi ed.). California: Wadsworth Group.

Nurfajriyani, I., Prabandari, Y. S., \& Lusmilasari, L. (2016). Influence of video modelling to the toileting skill at toddler. International Journal of Community Medicine and Public Health, 3(8), 2019-2034.

Ogelman, H. G. (2012). Teaching preschool children about nature a project to provide soil education for chidren in Turkey. Early Childhood Education Journal, 40(3), 177-185.

Pursubaryanto, E. (2005). Wayang Kancil di Indonesia: Bentuk, fungsi, dan dinamika kehidupannya. Universitas Gadjah Mada.

Pusat Data Wayang Indonesia. (2011). Wayang Kancil. Retrieved June 26, 2013, from http://pdwi.org/index.php?option=com_content\&view=article\&id=161:wayangkancil\&catid=71:jenis-wayang-indonesia\&Itemid=18

Sahu U., Roy M., Rajkiranl M., R. (2015). ENVIRONMENTAL AWARENESS AMONG PG STUDENTS . International Journal of Pharmacology \& Biological Sciences, 9(1), 65-70. 
Sanchez, T. R., \& Stewart, V. (2006). The remarkable Abigail: Story-telling for character education. The High School Journal, 89(4), 14-21.

Santrock, J. W. (2002). Life span development edisi ke-5. Terjemahan. Jakarta: Erlangga.

Sarafino, E. P. (2005). Applied behavior analysis: Principle and procedures for modifying behavior. New Jersey: Hoboken.

Sasrawijaya, R. P. (1986). Serat Kancil 1. Dialihbahasakan oleh Sri Suharini. Jakarta: Departemen Pendidikan dan Kebudayaan. Proyek Penerbitan Buku Sastra Indonesia dan Daerah.

Saville, B. K., \& Buskist, W. (2005). Traditional idiographic approaches: Small-N research designs. In S. F. Davis (Ed.), Handbook of research methods in experimental psychology. Massachusetts.

Sharma, S. and C. S. (2017). Microplastic pollution, a threat to marine ecosystem and human health : a short review. Environmental Science and Pollution Research September, 24(27), 21530-21547.

Suhantojo. (2013). Pembelajaran dengan Metode Mendongeng untuk Meningkatkan Perilaku Membuang Sampah di Tempat yang sesuai pada Siswa Kelas 3 Sekolah Dasar. Universitas Katolik Soegijapranata.

Suyadi. (2014). Manajemen PAUD TPA-KB-TK/RA mendirikan, mengelola, dan mengembangkan PAUD (Pendidikan Anak Usia Dini). Yogyakarta: Pustaka Pelajar.

Tarnoto, N. (2013). Peningkatan sikap peduli lingkungan melalui bermain peran "Aku Sayang Bumiku" pada anak prasekolah. Universitas Gadjah Mada.

Thote, P. (2013). STUDY OF ATTITUDE OF STUDENTS TOWARDS ENVIRONMENTAL AWARENESS : A CASE STUDY, 1(1).

Tondok, M. S. (2006). 'Menyampah' dari Perspektif Psikologi (1).

Tuncay, B., Yilmaz-Tuzun, O., \& Tuncer-Teksoz, G. (2011). The relationship between environmental moral reasoning and environmental attitudes of pre-service science teachers. International Electronic Journal of Environmental Education, 1(3), 167-178.

Wardani, P. K. (2015). Validitas modul permainan kartu bergambar "memelihara lingkunganku" untuk meningkatkan sikap peduli lingkungan pada anak usia dini. Universitas Gadjah Mada.

Wilson, D. C., Rodic, L., Modak, P., Soos, R., Rogero, A. C., Velis, C., ... Simonett, O. (2015). The global solid waste management outlookunited nations environment. (D. C. Wilson, Ed.). United Nations Environment Programme.

Wilson, R. A. (1994). Environmental Education at the Early Childhood Level. North American Association for Environmental Education, P.O. Box 400, Troy, OH 45373.

Winarsih, T. (2014). Dongeng menggunakan wayang kancil untuk meningkatkan pengetahuan tentang perilaku prososial anak usia dini. Universitas Gadjah Mada. Retrieved from http://etd.repository.ugm.ac.id/index.php?act=view\&buku_id=74757\&mod=penelitian_det ail\&sub=PenelitianDetail\&typ=html

Wright, C., Bacigalupa, C., Black, T., \& Burton, M. (2008). Windows into children's thinking: A 
guide to storytelling and dramatization. Early Childhood Education Journal, 35(4), 363-369.

Yanuvianti, M. (2008). Menggunakan Anjuran dan Imbalan sebagai Intervensi untuk Mengurangi Perilaku Membuang Sampah di Sembarang Tempat pada Siswa Sekolah Dasar. Universitas Gadjah Mada.

Yoleri, S. (2012). Children and the environment: Creating environment awareness among preschool childern. Buca Faculty of Education Journal, 34, 100-111.

Yulida, N. (2015). Analisa Perilaku Masyarakat di Daerah Alira Sangau Batang Bakerek-Karek Kota Padang Panjang Sumatera Barat dalm Membuang Sampah. Universitas Gadjah Mada. 